\title{
HUBUNGAN JENIS PERSALINAN DENGAN KEJADIAN SEPSIS NEONATORUM DI RSUP PROF. DR. R. D. KANDOU MANADO
}

\author{
Maria Y. Lihawa' ${ }^{1)}$, Max Mantik², Rocky Wilar') \\ Bagian Ilmu Kesehatan Anak Fakultas Kedokteran Universitas Sam Ratulangi Manado
}

Email: sintha_lihawa@rocketmail.com

\begin{abstract}
Neonatal sepsis is a bacterial infection that occurs in neonates which happens during the first months of life. WHO estimated that sepsis neonatorum cause 1 billion death every year, which accounts for $10 \%$ of all death below age 5 . In developing countries, death because of sepsis is about 34 per 1000 birth and for developed countries it is only 5 per 1000 birth. There are some factors triggering neonatal sepsis that come from the mother, these factors include: preterm labor and birth, premature rupture membrane more than 18-24 hours, chorioamnionitis, usage of device during labor, maternal fever $\left(>38^{\circ} \mathrm{C}\right)$, maternal UTI, and mother's nutrition. There are also factors that come from the baby itself, include: perinatal asphyxia, low birth weight, preterm birth, invasive procedure, and congenital abnormality. The aim of this study is to find out the correlation between types of delivery and the incident of neonatal sepsis. This study was conducted in RSUP Prof. DR. R.D. Kandou Manado from August 2012 - August 2013. This is a retrospective analytic study, using total sampling method. Data were obtained from the medical records. Analysis using chi square shows a significant correlation between types of delivery and incident of neonatal sepsis $(P=0.001)$.
\end{abstract}

Key word: sepsis neonatal, neonatal infection, risk factor of sepsis.

\begin{abstract}
Abstrak: Sepsis neonatorum adalah infeksi bakteri pada neonatus yang terjadi selama bulan pertama kehidupan. WHO memperkirakan 1 juta kematian per tahun (10\% dari jumlah kematian berusia dibawah lima tahun) karena sepsis neonatal. Di negara berkembang, kematian neonatus dari seluruh penyebab sepsis kira-kira 34/1000 kelahiran dan di negara maju, hanya sekitar 5/1000 kelahiran.Ada beberapa faktor pencetus sepsis neonatorum yaitu faktor dari ibu (persalinan dan kelahiran kurang bulan, ketuban pecah lebih dari 18-24 jam, korioamnionitis, persalinan dengan tindakan, demam pada ibu $\left(>38,4^{\circ} \mathrm{C}\right)$, ISK pada ibu, dan gizi ibu).Dan faktor dari bayi (asfiksia perinatal, berat lahir rendah, bayi kurang bulan, prosedur invasif dan kelainan bawaan).Tujuan penelitian ini untuk mengetahui hubungan jenis persalinan dengan kejadian sepsis neonatorum.Penelitian ini dilakukan di RSUP Prof. Dr. R. D. Kandou Manado periode Agustus 2012- Agustus 2013. Penelitian ini bersifat analitik retrospektif yang diambil dalam bentuk data rekam medik dengan pengambilan sampel menggunakan teknik total sampling.Data yang dikumpulkan diolah dengan menggunakan uji Chi-square. Dari hasil analisa data didapatkan nilai $P=0,001(P<0,05)$. Nilai ini menunjukkan bahwa terdapat hubungan yang signifikan antara jenis persalinan dengan kejadian sepsis neonatorum.
\end{abstract}

Kata kunci: sepsis neonatorum, infeksi neonatus, faktor risiko sepsis. 
Sepsis neonatorum merupakan salah satu penyebab tersering kematian pada neonatus. ${ }^{1}$ Insiden dari sepsis neonatal bervariasi dari 1-4/1000 kelahiran pada negara maju dan 1050/1000 kelahiran di negara berkembang. ${ }^{2}$ Laporan WHO yang dikutip dari State of world's mother 2007 dilaporkan bahwa 36\% kematian neonatus disebabkan oleh penyakit infeksi, diantaranya sepsis, pneumonia, tetanus, dan diare. WHO juga melaporkan case fatality rate yang tinggi (40\%) pada kasus sepsis neonatus. ${ }^{2}$ Di Malaysia insiden sepsis neonatal $5-10 \% .{ }^{3}$ Insiden tingkat kejadian sepsis neonatorum di beberapa rumah sakit rujukan di Indonesia sekitar 8,7 - 30,29\% dengan angka kematian 11,56 - 49,9\%. Di RSCM dilaporkan bahwa pada Januari - September 2005 angka kejadian sepsis sekitar 13,68\%. ${ }^{4}$

Risiko dari sepsis neonatal multifaktorial dan berhubungan dengan belum matangnya sistem humoral, fagosit dan imunitas seluler (biasanya terjadi pada bayi prematur dan berat bayi lahir rendah), hipoksia, asidosis dan gangguan metabolisme. Insiden sepsis neonatal juga dipengaruhi oleh status ekonomi, proses persalinan, ras, jenis kelamin (laki-laki 4 kali lebih mudah terinfeksi dari pada perempuan), dan standar perawatan bayi. ${ }^{3}$

Sepsis neonatus dibagi menjadi sepsis neonatorum awitan dini (SNAD) dan sepsis neonatorum awitan lambat (SNAL). SNAD timbul dalam 72 jam pertama kehidupan dan ditularkan perinatal dari ibunya, sedangkan SNAL timbul setelah 72 jam dan didapatkan pascanatal dari lingkungan, biasanya sering ditemukan pada bayi yang dirawat di ruang intensif BBL, BKB yang lama dirawat, nutrisi parenteral yang berlarut-larut, infeksi dari alat perawatan bayi, infeksi nosokomial atau infeksi silang dari bayi lain atau dari tenaga medis yang merawat. ${ }^{1,5}$ Berhubungan dengan proses persalinan bahwa insiden sepsis neonatal lebih banyak pada kasus bayi yang lahir melalui seksio sesarea dibandingkan dengan lahir secara spontan. Studi sebelumnya yang dilakukan di RS Dr. Soetomo mengemukakan bahwa bayi yang lahir dengan seksio sesarea mempunyai risiko terjadi sepsis 1,89 kali lebih tinggi daripada yang tidak melakukan seksio sesarea. ${ }^{4}$

\section{Metode}

Penelitian ini bersifat analitik retrospektif dengan memanfaatkan data sekunder berupa catatan medik.Penelitian ini dilakukan di Bagian Ilmu Kesehatan Anak RSUP Prof. Dr. R. D. Kandou Manado pada bulan November sampai Desember 2013. Pengambilan sampel pada penelitian ini menggunakan teknik total sampling yaitu semua data dari catatan medik bayi penderita sepsis neonatorum periode Agustus 2012- Agustus 2013. Kriteria inklusi adalah bayi yang dilahirkan yang menderita sepsis neonatorum.Sedangkan kriteria eksklusi adalah bayi yg menderita kelainan bawaan yang berat. Variabel penelitian yang diteliti adalah jenis persalinan, BBLR, bayi prematur, bayi dengan nilai Apgar rendah, ibu dengan KPD $>18$ jam, ibu dengan demam intrapartum $>38^{\circ} \mathrm{C}$. Data yang didapat dianalisis dengan uji Chi-square dan diolah dengan menggunakan teknik komputerisasi SPSS. Dikatakan berhubungan signifikan antara jenis persalinan dengan kejadian sepsis neonatorum apabila $\mathrm{p}<0,05$.

\section{Hasil dan Pembahasan}

Pada Agustus 2012 - Agustus 2013 didapatkan dari 4659 total kelahiran terdapat 215 bayi lahir yang menderita sepsis neonatorum.

Tabel 1. Distribusi sampel berdasarkan berat badan bayi

\begin{tabular}{ccc}
\hline Berat badan lahir & Jumlah (n) & Persentase (\%) \\
\hline$<2500$ gr & 58 & 27 \\
$2500-4000$ gr & 140 & 65,1 \\
\hline
\end{tabular}




\begin{tabular}{ccc}
\hline$>4000$ gr & 17 & 7,9 \\
\hline Total & 215 & 100 \\
\hline
\end{tabular}

Tabel 2. Distribusi sampel berdasarkan umur kehamilan

\begin{tabular}{ccc}
\hline Umur Kehamilan & Jumlah (n) & Persentase (\%) \\
\hline$<37$ minggu & 56 & 26 \\
$37-42$ minggu & 159 & 74 \\
\hline Total & 215 & 100 \\
\hline
\end{tabular}

Didapatkan jumlah penderita sepsis neonatorum paling banyak $(65,1 \%)$ pada bayi dengan berat badan lahir 2500-4000 gr dan yang lahir dengan umur kehamilan 37-42 minggu (74\%).Berbeda dengan teori yang menyatakan bahwa salah satu faktor risiko terjadi sepsis adalah berat badan lahir rendah (BBLR) dan bayi prematur.Hal ini terjadi karena bayi - bayi berat lahir rendah dan premature pematangan organ tubuhnya (hati, paru, pencernaan, otak, sistem imunitas) masih belum matang sehingga bisa menjadi faktor predisposisi terjadinya infeksi. ${ }^{6}$ Penelitian sebelumnya di RS. Dr. Soetomo, bahwa BBLR pada bayi memiliki risiko sepsis 2,75 kali lebih tinggi. Dan juga persalinan prematur juga berisiko 4 kali lebih tinggi dibandingkan bayi-bayi yang lahir cukup bulan. ${ }^{4}$

Tabel 3.Distribusi sampel berdasarkan nilai Apgar.

\begin{tabular}{ccc}
\hline Nilai Apgar & Jumlah (n) & Persentase (\%) \\
\hline Rendah & 130 & 60,5 \\
Normal & 85 & 39,5 \\
\hline Total & 215 & 100 \\
\hline
\end{tabular}

Untuk nilai Apgar bayi sepsis neonatorum terbanyak adalah nilai Apgar rendah.Seperti penelitian sebelumnya di Rumah Sakit Umum Dr. Saiful Anwar Malang, bayi baru lahir dengan nilai Apgar rendah memiliki proporsi terbanyak.Ini disebabkan terdapat hubungan erat antara nilai Apgar rendah dan infeksi.Nilai Apgar menit pertama $<7$ memerlukan prosedur intervensi yang lebih yang bisa meningkatkan risiko terjadinya infeksi nosocomial. Penelitian Wong et al menambahkan bahwa nilai Apgar yang rendah saat menit pertama meningkatkan kebutuhan prosedur ventilasi mekanik dan pemasangan kateter umbilikal sehingga meningkatkan risiko terjadinya sepsis pada bayi baru lahir. ${ }^{7}$

Tabel 4.Distribusi sampel berdasarkan faktor risiko ibu dengan ketuban pecah dini.

\begin{tabular}{ccc}
\hline KPD & Jumlah (n) & Persentase (\%) \\
\hline$>18$ jam & 125 & 58,1 \\
$<18$ jam & 90 & 41,9 \\
\hline Total & 215 & 100 \\
\hline
\end{tabular}

Distribusi sampel berdasarkan faktor risiko ibu dengan ketuban pecah dini yang paling banyak ditemukan adalah KPD >18 jam. Hasil yang hampir sama yang dilakukan di RSUD Curup Rejang Lebong bahwa status ketuban berhubungan dengan kejadian sepsis neonatorum. Bayi yang lahir dari ibu dengan KPD berisiko mengalami sepsis neonatorum 7,595 kali.Hal ini dapat terjadi karena infeksi neonatus setelah pecah ketuban dipengaruhi oleh kolonisasi kuman streptococcus grup beta. Lama ketuban pecah berhubungan dengan peningkatan koloni kuman, infeksi ascending dan jumlah pemeriksaan vagina. ${ }^{8}$

Tabel 5.Distribusi sampel berdasarkan faktor risiko ibu dengan demam intrapartum.

\begin{tabular}{ccc}
\hline Demam Intrapartum & Jumlah (n) & Persentase (\%) \\
\hline
\end{tabular}




\begin{tabular}{ccc}
\hline$>38^{\circ} \mathrm{C}$ & 144 & 67 \\
$<38^{\circ} \mathrm{C}$ & 71 & 33 \\
\hline Total & 215 & 100 \\
\hline
\end{tabular}

Berdasarkan faktor risiko ibu dengan demam intrapartum $>38^{\circ} \mathrm{C}$ didapatkan sebanyak 144 bayi dan 71 bayi penderita sepsis lahir dari ibu dengan demam intrapartum $<38^{\circ} \mathrm{C}$. Infeksi neonatal dapat terjadi intrauterine melalui transplasental, didapat intrapartum saat melalui jalan lahir selama proses persalinan atau pascapartum akibat sumber infeksi dari luar setelah lahir. Infeksi intrapartum dapat terjadi pada saat melalui jalan lahir atau infeksi ascendens bila terjadi partus lama dan ketuban pecah dini. ${ }^{9}$

Tabel 6.Hubungan jenis persalinan dengan kejadian sepsis neonatorum

\begin{tabular}{cccc}
\hline \multirow{2}{*}{ Jenis persalinan } & \multicolumn{2}{c}{ Sepsis } & \multirow{2}{*}{$\mathrm{P}$} \\
\hline Spontan & Jumlah (n) & Persentase (\%) & \\
Seksio Sesarea & 122 & 3,9 & \multirow{2}{*}{0,001} \\
Ekstraksi Vakum & 16 & 5,6 & \\
Ekstraksi Forceps & 0 & 10,5 & \\
\hline
\end{tabular}

Berdasarkan tabel diatas bahwa bayi yang lahir dengan ekstraksi vakum berisiko untuk terjadi sepsis neonatorum.Hasil penelitian ini sesuai dengan teori yang menyatakan bahwa bayi yang lahir dengan tindakan lebih berisiko terjadi sepsis neonatorum.Hal ini terjadi karena kontaminasi kuman yang terjadi setelah lahir, seperti alat-alat yang digunakan saat dilakukan pertolongan persalinan.Demikian juga Saifuddin menyatakan bahwa bayi baru lahir berisiko tinggi terinfeksi apabila ditemukan bayi dengan riwayat kelahiran dengan tindakan. Infeksi dapat diperoleh bayi dari lingkungannya diluar rahim ibu, seperti alat-alat penolong persalinan yang terkontaminasi. ${ }^{8}$

\section{Kesimpulan}

Dari penelitian ini disimpulkan bahwa adanya hubungan bermakna antara jenis persalinan dengan kejadian sepsis neonatorum.Angka kejadian sepsis neonatorum sebanyak 4,6\% pada periode Agustus 2012 - Agustus 2013. Bayi yang lahir dengan tindakan (ekstraksi vakum) berisiko tinggi untuk terjadi sepsis neonatorum. Oleh karena itu perlu dipantau tentang sterilisasi penggunaan alat-alat pertolongan persalinan.Keterbatasan penelitian ini adalah peneliti tidak menilai faktor-faktor risiko lainnya yang berhubungan dengan sepsis neonatorum.Selain itu kurangnya data yang lengkap sehingga peneliti tidak merinci tentang klasifikasi sepsis neonatorum.

\section{Daftar Pustaka}

1. Wilar R, Kumalasari E, Suryanto DY, Gunawan S. Faktor risiko sepsis awitan dini. Sari Pediatri. 2010;12:265-8.

2. Putra PJ. Insiden dan faktor-faktor yang berhubungan dengan sepsis neonatus di RSUP Sanglah Denpasar. Sari Pediatri. 2012;14:205-10.

3. Kardana IM. Incidence and factors associated with mortality of neonatal sepsis. Paediatr Indones. 2011;51:144-7.

4. Utomo MT. Risk factors of neonatal sepsis : A preliminary study in Dr.Soetomo Hospital. Indonesian journal of tropical and infectious disease. 2010;1:23-26.

5. Aminullah A. Sepsis pada bayi baru lahir. Dalam: Kosim MS, Yunanto A, Dewi R, Sarosa GI, Usman A, penyunting. Buku ajar neonatalogi. Edisi I. Penerbit IDAI; 2010.h.171-183.

6. Carolus W, Rompis J, Wilar R. Hubungan Apgar skor dan berat badan lahir dengan sepsis neonatorum. E-clinic. 2013;1. 
7. Sulistijono E, Lintang S, Kristina A. Faktor risiko sepsis awitan dini pada neonatus. Jurnal Kedokteran Brawijaya. 2013;27:232-5.

8. Simbolon D. Faktor risiko sepsis pada bayi baru lahir di RSUD Curup kabupaten Rejang Lebong. Diunduh dari : $\quad$ http://isjd.pdii.lipi.go.id/admin/jurnal/36308127134_01259695.pdf.

9. Kosim MS. Infeksi neonatal akibat air ketuban keruh. Sari Pediatri. 2009;11:212-8. 